Journal of Community Based Environmental Engineering and Management, 2021, Vol. 5, No. 1: 15-21

\title{
COMMUNITY PARTICIPATION IN WASTE MANAGEMENT IN BATUNUNGGAL INDAH RESIDENTIAL AREA, BANDUNG, INDONESIA
}

\author{
Anni Rochaeni ${ }^{*}$, Ria Ismaria, Dede Sulaeman, Bryan Yogi Nurfryatna \\ Departement of Environmental Engineering, Universitas Pasundan
}

\begin{abstract}
Batununggal Indah housing still faces obstacles in waste management due to the low awareness of the community to separate and sort waste. Therefore, this area is the target of implementing waste management assistance carried out by the Bandung City Environment and Sanitation Service (DLHK) in collaboration with the City Government of Kawasaki, Japan. This study aims to evaluate the implementation of the waste management program in Permai and Jelita Clusters by identifying activities, changing community behavior and calculating changes in the amount of waste that is disposed of at the final disposal site. The evaluation results show that the main activity that has been carried out is a social approach in the form of workshops and counseling. Measurement of waste generation shows a decrease in the weight of generated waste that is disposed of at the final disposal site, indicating that waste separation has been practiced. This decrease is still insignificant because the community has not consistently carried out sorting behavior, so it needs sustainable encouragement.
\end{abstract}

Keywords: waste management, $3 R$, waste separation

\section{Introduction}

The waste problem is often stated as an urban issue in Indonesia (Yustiani et al, 2019). One of the southern parts of Bandung, to be precise in the Batununggal Indah Housing, is managed by a private company (IWABI) engaged in cleaning services established by the community in Batununggal Indah Housing. Community participation in managing the domestic waste is very important (Omran et.al, 2009) (Rusmaya et.al, 2019). Batununggal Indah still faces a major obstacle, namely the low awareness of the community to sort waste in an effort to reduce

Corresponding Author:

E-mail: *)anni_rochaeni@unpas.ac.id

Received: 10 Agustus 2020

Revised : 25 September 2020

Accepted: 9 February 2021 the waste that enters the temporary waste storage site (TPS) which will later be transported to the final disposal site. One solution to overcome this problem is through the development of sorting at the source, utilizing waste into organic fertilizer which is a social engineering activity that teaches people to sort waste and fosters public awareness in managing waste wisely and in turn reduces waste transported to the final disposal site. Efforts to increase public awareness in housing are carried out by promotion, socialization and counseling carried out by the Bandung City Environment and Sanitation Office (DLHK) in collaboration with the City Government of Kawasaki. Based on these conditions, this study aims to evaluate the waste management program in the Jelita Cluster and the Batununggal Indah Permai Cluster. In addition, this study seeks to determine the constraints of the community in sorting out 
waste sources that affect the reduction of waste to TPS.

\section{Research Methodology}

Research sites

The research location is Batununggal Indah Housing, focused on the Jelita Cluster and the Permai Cluster. This housing estate is located in Mengger Village, Bandung Kidul District, Bandung City, Indonesia. Evaluation of waste management is carried out with several activities, namely the measurement of waste generation that occurs, the implementation of programs carried out by the Bandung City Environment and Sanitation Service, and the community's reaction to the implemented program.

Measurement of waste generation is carried out in accordance with SNI M-36-1991-2003 concerning Methods for Taking and Measuring Samples of Generation and. Composition of Municipal Waste. This measurement is carried out before and after implementing the waste management program. Monitoring is carried out 3 times to see the sustainability of the program and the level of community participation.

Interviews were also conducted to obtain an overview of community opinions and the obstacles faced.

\section{Result and Discussion}

Implementation of Waste Management Program

There are several activities carried out by a team from the Bandung City Environment and Sanitation Service in waste management at Batununggal Indah Housing, including the socialization approach to the community. Table 1 shows the details of the activities carried out.

Table 1. Socialization Approach Activities to the Community (https://www.iges.or.jp/, accessed December 2020)

\begin{tabular}{lll}
\hline No & Activity & Description \\
\hline 1 & $\begin{array}{l}\text { First } \\
\text { meeting }\end{array}$ & $\begin{array}{l}\text { Before the workshop, an FGD was } \\
\text { held in the target area. This FGD }\end{array}$ \\
\hline
\end{tabular}

\begin{tabular}{|c|c|c|}
\hline No & Activity & Description \\
\hline & & $\begin{array}{l}\text { discusses the basics of waste } \\
\text { management and the stages of } \\
\text { compiling a waste management } \\
\text { action plan }\end{array}$ \\
\hline 2 & $\begin{array}{l}\text { Field visit } \\
\text { to Mentor } \\
\text { Area }\end{array}$ & $\begin{array}{l}\text { - Target Area visited the four } \\
\text { mentor area locations to learn } \\
\text { various } 3 \mathrm{R} \text { practices and share } \\
\text { experiences } \\
\text { - While in the field, representatives } \\
\text { from the mentor area explain to } \\
\text { the participants about waste } \\
\text { management in their area and } \\
\text { share knowledge, experiences } \\
\text { and problems with the solutions } \\
\text { that have been carried out. } \\
\text { - All field visit participants are } \\
\text { expected to be able to bring } \\
\text { knowledge and teachings from } \\
\text { KBS mentors as a reference for } \\
\text { discussion of action plans to be } \\
\text { carried out in their respective } \\
\text { regions }\end{array}$ \\
\hline 3 & $\begin{array}{l}\text { Field Visit } \\
\text { to } \\
\text { Sukaluyu } \\
\text { Area }\end{array}$ & $\begin{array}{l}\text { KBS Sukaluyu is not KBS mentor } \\
\text { in Kawasaki Bandung activities } \\
\text { but the target area can learn about } \\
\text { waste collection that has been } \\
\text { carried out well in the Sukaluyu } \\
\text { area. }\end{array}$ \\
\hline 4 & Workshop & $\begin{array}{l}\text { - Based on knowledge and sharing } \\
\text { of experiences from field visits to } \\
\text { KBS mentors, each target area is } \\
\text { asked to discuss and determine } \\
\text { the waste management system } \\
\text { and method that is considered } \\
\text { appropriate and can be done in } \\
\text { their respective areas. } \\
\text { - Develop a waste management } \\
\text { system and a waste management } \\
\text { action plan. }\end{array}$ \\
\hline 5 & $\begin{array}{l}\text { Workshop } \\
\text { for High } \\
\text { Economic } \\
\text { Target } \\
\text { Areas }\end{array}$ & $\begin{array}{l}\text { - Sharing objectives, constraints, } \\
\text { status in implementing waste } \\
\text { sorting } \\
\text { - Discussion of strategies to } \\
\text { improve waste separation at } \\
\text { source } \\
\text { - Discussing the appropriate } 3 \mathrm{R} \\
\text { facilities in Batununggal } \\
\text { - Develop a waste management } \\
\text { system and action plan } \\
\end{array}$ \\
\hline
\end{tabular}

Another activity is the installation of banners with information stating that this community is one of the "Free Garbage Areas" guided and supported by the Kawasaki-DLHK Project. The banners can be seen in Figure 1 and Figure 2. 


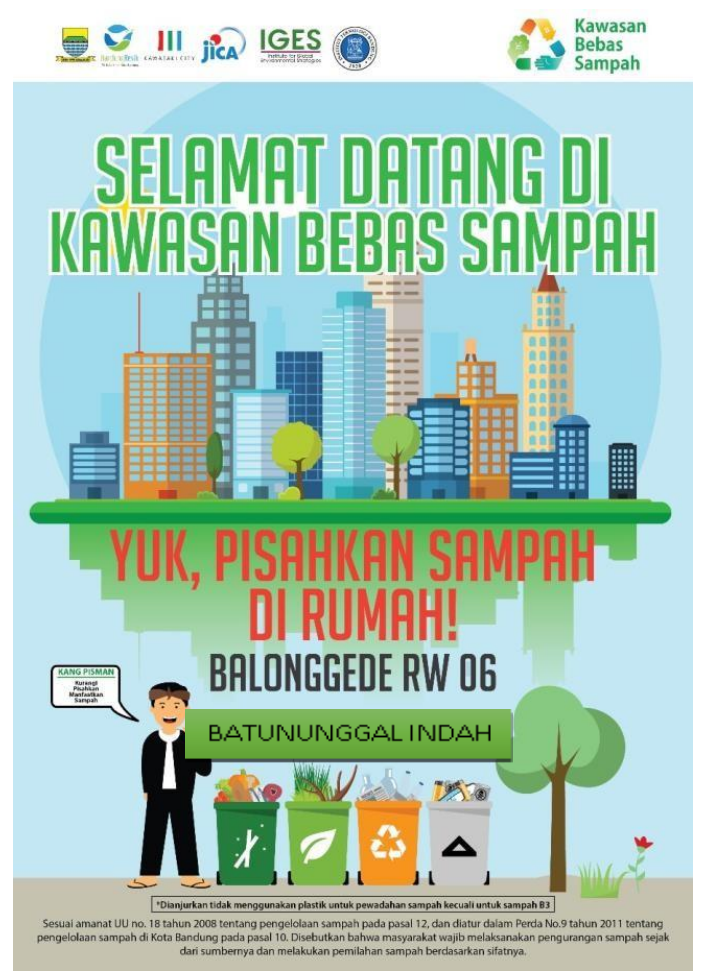

Figure 1.Vertical banner (IGES 2017)

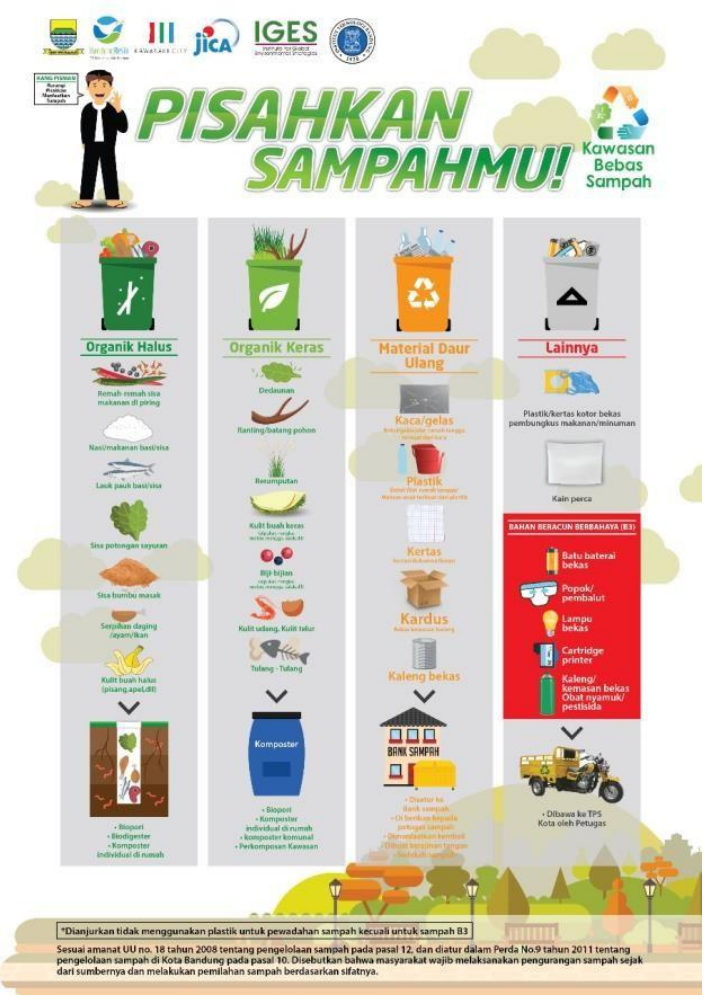

Figure 2. Poster of information of waste type to be sorted (https://www.iges.or.jp/, accessed December 2020).
The waste management system in Batununggal Indah Housing uses a collection and transport system, where the waste management system is not carried out in advance at the source so that the waste that is disposed of at the TPS does not reduce the volume of waste. However, after the existence of the KBS (Zero Waste Area) program from DLHK Bandung City in collaboration with the Japanese Kawasaki City Government, the existing waste management system at the Batununggal Indah household, especially in the Jelita Cluster and the Permai Cluster, became a disaggregated system where this system was separated in sources to reduce the volume of waste that enters the TPS.

\section{Monitoring of Waste Reduction to TPS}

The sorted waste (organic waste) and other waste from the Jelita Cluster and the Permai Cluster will be transported by the garbage officer (IWABI), then taken to the TPS Batununggal Indah. Organic waste will be processed at TPS in Batununggal Indah, other waste will be sorted by garbage collectors at TPS and the rest will be transported to the final disposal site. Figure 3 shows the waste generation from the Permai Cluster during 3 monitoring times.

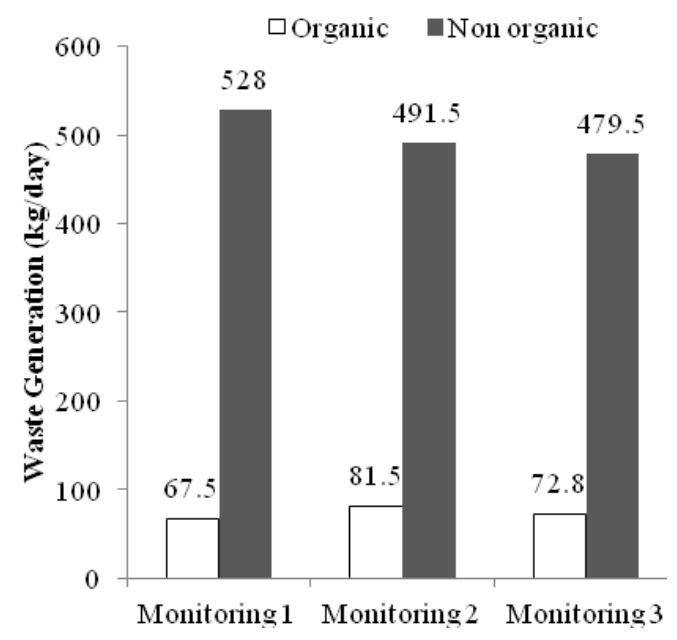

Figure 3. Data on the amount of waste $(\mathrm{kg} /$ day) in the Permai Cluster. 
Analysis of the level of waste reduction to the TPS in the Permai Cluster:

\section{Monitoring 1}

In monitoring 1 , the number of houses sorting out as many as 40 houses with organic waste which is separated $11.3 \%$ of the total waste of $595.5 \mathrm{~kg} /$ day in the scenic cluster which will be transported to the TPS every day. The sorted organic waste will be processed by TPS Batununggal Indah.

\section{Monitoring 2}

In monitoring 2 , the number of houses sorting out as many as 40 houses with organic waste which is separated by $14.2 \%$ of the total waste $573 \mathrm{~kg} /$ day in the scenic cluster which will be transported to the TPS every day. The sorted organic waste will be processed by TPS Batununggal Indah

\section{Monitoring 3}

In monitoring 1, the number of houses sorting out 43 houses with organic waste which is separated by $13.2 \%$ of the total $552 \mathrm{~kg} /$ day waste in the scenic cluster which will be transported to the TPS every day. The sorted organic waste will be processed by TPS Batununggal Indah.

In the analysis of the level of waste reduction above, it can be seen that the progress of the level of waste reduction to TPS in monitoring 1 to monitoring 2 has experienced a quite high change from the initial $37.8 \mathrm{~kg} /$ day of organic waste from the total waste of $302.1 \mathrm{~kg} /$ day and the number of houses which sorted the waste are 25 houses, making it $72.8 \mathrm{~kg}$ /day from the total waste of $552.3 \mathrm{~kg} / \mathrm{day}$ and with 43 houses sorting out. This was caused by intensive mentoring. Consistent monitoring will increase public awareness (Yukalang et.al, 2018).

Figure 4 shows the waste generation from the Jelita Cluster during 3 monitoring times.

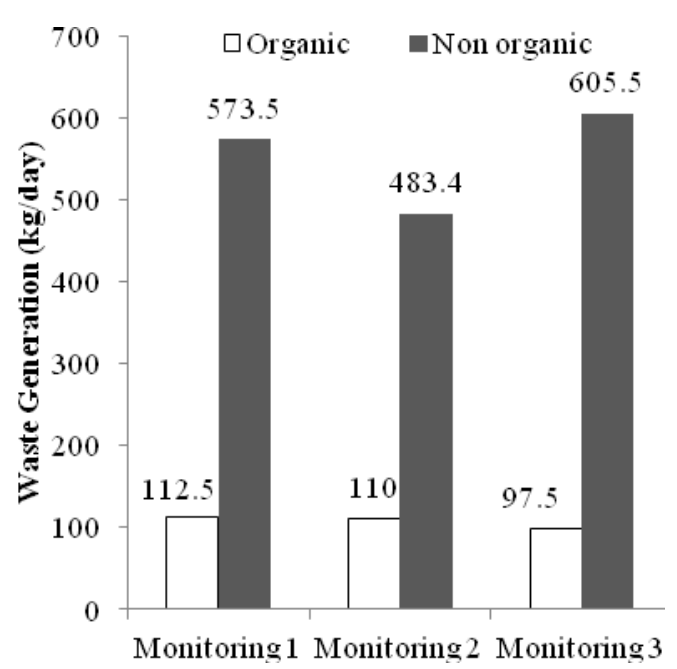

Figure 4. Data on the amount of waste $(\mathrm{kg} /$ day) in the Jelita Cluster

Analysis of the level of waste reduction to the TPS in the Jelita Cluster

\section{Monitoring 1}

In monitoring 1 , the number of houses sorting out as many as 31 houses with organic waste which was separated $16.4 \%$ of the total waste $686 \mathrm{~kg} /$ day in beautiful clusters which would be transported to the TPS every day. The sorted organic waste will be processed by TPS Batununggal Indah.

\section{Monitoring 2}

In monitoring 2, the number of houses sorting out as many as 31 houses with organic waste which is separated by $18.5 \%$ of the total waste of $593.4 \mathrm{~kg} /$ day in the scenic cluster which will be transported to the TPS every day. The sorted organic waste will be processed by TPS3R Batununggal Indah.

\section{Monitoring 3}

In monitoring 1 , the number of houses sorting out 34 houses with organic waste, which is separated by $13.9 \%$ of the total $703 \mathrm{~kg} /$ day waste in the scenic cluster which will be transported to the TPS every day. The sorted 
organic waste will be processed by TPS Batununggal Indah

In the analysis of the level of waste reduction in the Jelita Cluster, there was a fairly high progress, from the initial $33.4 \mathrm{~kg} /$ day of organic waste that was separated from the total waste of $396.6 \mathrm{~kg} /$ day and with the number of houses sorting 15 houses to $97.5 \mathrm{~kg} /$ day organic waste is separated from the total waste of $605.5 \mathrm{~kg} /$ day with 34 houses sorting out.

However, the progress of reducing waste is not only seen from how much waste can be processed but also in terms of how many houses are sorting it out and also to foster a sense of community care for the environment.

From Figure 3 and Figure 4 it can be seen that the reduction of waste obtained by the two clusters is quite influential in reducing the volume of waste to the TPS, with the source separation system, the waste that should be wasted from one cluster is $595.5 \mathrm{~kg} /$ day to 528 $\mathrm{kg} /$ day. However, the waste that is processed by the garbage officer (IWABI) in this project is only organic waste.

Waste Separation at the Source by the Community

Sorting is the separation by classifying 2 types of waste, namely organic waste and other waste, the sorting process is very influential on reducing the volume of waste. This classification is a common separation and sorting of domestic waste in Indonesia (Hasbiah et.al, 2019).

Based on observations, the sorting operation did not go well because:

- Some people do not want to separate because the garbage collectors always mix sorted organic waste with other waste.

- Changes of household members in several houses because the people living in these houses have been submitted to the household member for their waste sorting, the household member does not know about the waste separation, so initially the house is sorting to not sorting it because there is no direction.

- Lack of education about sorting out the community.

- Lack of monitoring of the KBS program, so that people do not see the seriousness of the government in this program which results in people not wanting to separate.

For the sorting operation to run better, the IWABI party should reprimand the officers who collect organic waste and other waste so that they are not mixed, and from the DLHK project, they conduct education at least once a month to convey about the waste-free area program so that the public knows and wants to sort it out. The DLHK conducts monitoring so that the public will believe and assess that the government really aware of this program.

\section{Waste Container}

Waste containerization is the activity of temporarily collecting waste before it is collected, moved, transported, processed and carried out by final processing of the waste at the final disposal site.

Based on the results of observations during research in the field, the waste packaging does not go well, this is because.

- The community does not place garbage according to their criteria such as organic waste and other waste in one place, while the waste management (IWABI) has provided a special organic container or bin, which results in the waste being mixed with other waste and will be carried to the TPS.

- The community does not place the trash in its place or hang the garbage from the trees, which results in officers being unable to distinguish organic waste from other waste. 


\section{Waste Collection}

Collection is the process of taking garbage from houses or the road to the TPS using a garbage truck.

Based on the results of observations during research in the field, garbage collection is not going well. This is because:

- Garbage collectors who mix organic waste and other waste into one so that they cannot be processed by officers who process organic waste, and in the end will be disposed of directly to the TPS without going through organic waste processing or composting.

- Officers do not bring special organic trash cans at the time of garbage collection so that the waste that has been sorted by the community is sometimes thrown away with other garbage.

For the collection operation to run more optimally, the officers should always be reminded by IWABI officers who have the authority so that garbage collectors always separate trash and carry special trash bins for organic waste.

\section{Waste Treatment}

The processing operation in Batunungal Indah is the processing of organic waste into compost. Based on the results of observations during research in the waste processing field it did not go well for some reasons:

- Batununggal Indah does not yet have an organic waste processing facility.

- The delay in processing disaggregated organic waste has resulted in an unpleasant odor in the TPS Batununggal environment

- The organic waste processing plant located in Babakan sari is far away, this has resulted in delays in processing organic waste

In order for processing to run smoothly, IWABI and DLHK work together to facilitate an organic waste processing facility so that the organic waste generated from the two clusters can be processed directly without having to take it to TPS Babakansari. It is hoped that with the existence of compost house in TPS Batununggal Indah, the community cares about the environment and is willing to do some sorting.

\section{Conclusion}

Garbage collection in the Operational Area of Bandung City, especially in the Batununggal Indah Housing Area, Bandung Kidul District, Mengger Village, is managed by a private company founded by the Batununggal Indah Housing community in Bandung.

Garbage collection in the Batunungal Indah Residential Area has problems such as when collecting organic waste at residents' houses, the garbage officer end ups mixes organic waste with other garbage that has been sorted by the residents so that it makes the community lazy to sort.

Measurement of waste generation shows a decrease in the weight of generated waste that is disposed of at the final disposal site, indicating that sorting has occurred. This decrease is still insignificant because the community has not consistently carried out sorting behavior, so it needs sustainable encouragement.

\section{References}

Hasbiah, A., Rusmaya, D., \& Apriani, D. (2019). Sanitasi Berbasis Masyarakat di Pesantren Putri Al-Itihad, Kabupaten Cianjur. Journal of Community Based Environmental Engineering And Management, 3(1), 1-8.

https://www.iges.or.jp/, accessed December 2020.

Omran, A., Mahmood A, Abdul A, Robinson GM. (2009). Investigating Household Attitude Toward Recycling of Solid Waste in Malaysia: A Case Study. International 
Journal of Environment. 3 (2).

Rusmaya, D., Rochaeni, A., \& Dewi, N. (2019). Penentuan Fasilitas Sanitasi Berdasarkan Persepsi Santri di Tahfidz Qur'an Madrasah Tsanawiyah (MTS) Assalam Kota Bandung. Journal Of Community Based Environmental Engineering And Management, 3(1), 15-24.

Yukalang, N., Clarke, B., Ross, K. (2018). Solid Waste Management Solutions for Rapidly
Urbanizing Area in Thailand: Recommendation Based on Stakeholder Input. Int. J. Environ. Res. Public Health, 15, 1302.

Yustiani, Y.M., Rochaeni, A., Aulia, A. (2019). Konsep Pengelolaan Sampah di Desa Babakan Kabupaten Bandung. EnviroScienteae, 15(1): 121-126. 